\title{
The in vitro efficacy of eye drops containing a bacteriophage solution specific for Staphylococcus spp. isolated from dogs with bacterial conjunctivitis
}

\author{
Renata Urban-Chmiel'10, Ireneusz Balicki², Katarzyna Świąder³, Anna Nowaczek', Ewelina Pyzik', \\ Dagmara Stępień-Pyśniak ${ }^{1}$, Agnieszka Marek ${ }^{1}$, Andrzej Puchalski ${ }^{1}$, Andrzej Wernicki ${ }^{1}$, Ewa Poleszak ${ }^{3}$ and \\ Marta $\operatorname{Dec}^{1 *}$ (1)
}

\begin{abstract}
Background: The purpose of the study was to evaluate the in vitro antibacterial effect of experimental eye drops with bacteriophages in elimination of Staphylococcus spp. isolated from dogs with bacterial conjunctivitis.. The bacterial material was collected from dogs with independent clinical signs of bacterial conjunctivitis. Staphylococcus spp. were identified by phenotypic and genotypic methods (MALDI-TOF MS mass spectrometry). Antibiotic resistance was determined by the disc-diffusion method. Phage activity (Plaque forming units, PFU) was determined on double-layer agar plates. Phages with lytic titres $>10^{8} \mathrm{PFU}$ were used to prepare eye drops. The stability of the antibacterial titre was evaluated for preparations stored in sealed bottles as well as after opening and reclosing.

Results: The tests confirmed the occurrence of Staphylococcus spp. strains as etiological agents of bacterial conjunctivitis in dogs. A high percentage of strains were resistant to more than three antibiotics. The experimental phage eye drops used in the study exhibited 100\% efficacy in vitro against the tested Staphylococcus isolates. Particularly noteworthy is the long duration of activity and constant antibacterial lytic titre of $\geq 10^{8} \mathrm{PFU} / \mathrm{mL}$ of two eye drop solutions, nos. 7 and 12, after the bottle had been opened (21 days) and after hermetically sealed packaging (28 days) at $4-8{ }^{\circ} \mathrm{C}$.

Conclusions: The results represent the first stage of research and require continuation in vivo. If positive effects are obtained in animals, the results can be used in applied research in humans and animals.
\end{abstract}

Keywords: Antibiotic resistance, Conjunctival diseases, Experimental medicine, Bacterial infections, Ophthalmology

\section{Background}

Bacterial conjunctivitis in dogs often caused by different Staphylococcus spp. strains is a frequently diagnosed health problem worldwide [1]. An important factor

\footnotetext{
*Correspondence: marta.dec@up.lublin.pl

'SubDepartment of Veterinary Prevention and Avian Diseases, Institute of Biological Bases of Animal Diseases, Faculty of Veterinary Medicine, University of Life Sciences Lublin, Lublin, Poland

Full list of author information is available at the end of the article
}

limiting the control and effective treatment of infections is the increasing multi-drug resistance of strains to the antibiotics used to treat them. Primary bacterial conjunctivitis is uncommon in dogs, rather it is often associated with other ophthalmic or systemic diseases [2]. Bacterial conjunctivitis should be diagnosed by comprehensive ophthalmic diagnostics, including the Schirmer test, Jones test, and corneal examination using a slit lamp [3, 4]. Diagnosis and monitoring may be facilitated

(c) The Author(s). 2020 Open Access This article is licensed under a Creative Commons Attribution 4.0 International License, which permits use, sharing, adaptation, distribution and reproduction in any medium or format, as long as you give appropriate credit to the original author(s) and the source, provide a link to the Creative Commons licence, and indicate if changes were made. The images or other third party material in this article are included in the article's Creative Commons licence, unless indicated otherwise in a credit line to the material. If material is not included in the article's Creative Commons licence and your intended use is not permitted by statutory regulation or exceeds the permitted use, you will need to obtain permission directly from the copyright holder. To view a copy of this licence, visit http://creativecommons.org/licenses/by/4.0/ The Creative Commons Public Domain Dedication waiver (http://creativecommons.org/publicdomain/zero/1.0/) applies to the data made available in this article, unless otherwise stated in a credit line to the data. 
by conjunctival cytology, which provides information regarding epithelial cell metaplasia, bacteria morphology, and staining characteristics - Gram-positive or negative [5-8]. In acute bacterial conjunctivitis, the dominant immune cells are neutrophils, with only a few mononuclear cells and degenerating epithelial cells. Bacterial cells also appear in the smear [3].

Symptoms of bacterial conjunctivitis include varying degrees of conjunctival redness, conjunctival oedema, and the presence of a purulent exudate of varying severity $[5,9-11]$. In cases of bacterial conjunctivitis, a detailed ophthalmological examination is often followed by bacterial culture and susceptibility. The most common pathogens isolated from conjunctivitis in dogs are Staphylococcus spp., Streptococcus spp., Bacillus spp., Pseudomonas spp., Corynebacterium spp., and Escherichia coli $[8,9]$.

Therapy for bacterial conjunctivitis must be combined with treatment of the primary disease. In its acute form, it is limited to administration of antibiotics into the conjunctival sac, in the form of ophthalmic solutions or ointments, and steroidal or non-steroidal anti-inflammatory drugs. In chronic conjunctivitis, local antibiotic therapy should be supplemented with the use of systemic antibiotics, after prior identification of the bacteria and their antibiotic resistance. In cases of Gram-positive bacterial infections, the most commonly used topical antibiotics are fluoroquinolones, erythromycin, bacitracin, neomycin, polymyxin $B$ and chloramphenicol, whereas Gram-negative infections are treated with aminoglycoside antibiotics $[4,11,12]$.

Methicillin-resistant strains of $S$. aureus (MRSA) are known to be responsible for serious hospital infections in humans, including bloodstream infections, pyomyositis or necrotizing fasciitis, osteomyelitis, septic arthritis, Waterhouse-Friderichsen syndrome, pneumonia, and bacteraemia [13]. The extensive spread of strains susceptible to only one group of antibiotics is a serious problem [14], especially as vancomycin-resistant strains isolated from humans, have already been noted, including in Poland [15]. A very important issue is the ease of transmission of pathogens from animals to humans. Animals infected with Staphylococcus spp. can pose a serious threat to humans, and the prevalence of these microorganisms increases the possibility of transmission of antibiotic resistance genes among staphylococci $[16,17]$.

Due to the increasing drug resistance among bacterial strains, there is a need to search for alternative methods to eliminate pathogens potentially responsible for the transfer of resistance genes. One alternative method is phage therapy, using bacteriophages isolated from the environments in which specific pathogens occur.

Bacteriophages, also called bacterial viruses, are 'natural killers' of bacteria. They are the most abundant form of life on earth (their total number is estimated at $10^{32}$ virions) and are present in diverse environments (e.g. wastewater, water bodies, soil, forest undergrowth, food products, animals and humans). Bacteriophages contain only one type of nucleic acid, DNA or RNA. They also possess a capsid, which is built of structural proteins. The presence of bacteriophages is a natural mechanism that has existed for billions of years, ensuring the proper balance of various bacteria in the natural environment. These viruses show specific affinity for individual types of bacteria [18].

Bacteriophages can be lytic or temperate form. The lytic cycle of bacteriophage multiplication comprises adsorption, i.e. attachment of the phage 'tail' proteins to a specific receptor on the of the bacterial cell's membrane; penetration of phage genome into the cytoplasm of the bacteria; assembly of new phages in the bacterial cells; and lysis of the cell wall. The progeny virions of the phages are released and infect additional bacteria. In the lysogenic cycle- temperate phages, not copied or expressed of DNA to make proteins, but recombines with the bacterial chromosome. In lysogenic cells, the phage exists in the form of DNA, called a prophage. Following integration with the host cell chromosome, the phage genome is lysogenized, or it may remain in the form of an episome. Lysogeny can continue for many generations, as long as the intracellular concentration of the active form of the repressor of lytic phage functions is sufficient to inhibit the transcription of early genes associated with lytic development [19].

Phages as antibacterial agents were first discovered more than 100 years ago, by Frederick Twort in 1915 and Felix d'Herelle in 1917 independently. Bacteriophages can be used to prevent and treat various bacterial infections, including zoonotic pathogens in livestock, with confirmed elimination of $99 \%$ or $100 \%$ of bacterial pathogens in poultry, cattle or pigs [20].

Each newly isolated bacteriophage is a valuable potential component of a preparation that could be used to treat bacterial infections. Given that many diseases cannot be treated using traditional methods and that the 'new' class of antibiotic (containing new structures and mechanism of antibacterial activity) was developed over 20 years ago, the possibility arises that we will be unable to treat infections in humans and animals.. The acquisition of 'new' phages is thus an important phenomenon in research centres, as not every phage meets the criteria (e.g. pH stability and lytic titre stability) for use as a component of an antibacterial preparation [21, 22].

In view of the increasing multi-drug resistance among bacteria and the need to find alternative methods to eliminate pathogens, the main purpose of this study was to assess the in vitro antibacterial effect of phages specific for Staphylococcus spp. strains isolated from dogs with symptoms of bacterial conjunctivitis, as an alternative to antibiotics in the elimination of infections. 


\section{Materials and methods Material collection}

The material was collected from dogs with clinical signs of bacterial conjunctivitis (about 120 independent cases) during standard diagnostic procedures. The animals were patients of the Department and Clinic of Animal Surgery at the University of Life Sciences in Lublin, and all samples were obtained during diagnostic procedures, such as evaluation of antibiotic resistance (antibiogram), which is essential for selecting antibiotic treatment. The owners were informed about the details of conducted clinical trials and they have given their consent. According to the present law in Poland (Experiments on Animals Act from January15th 2015, Journal of Laws of the Republic of Poland from 2015, item. 266), the study did not require the approval of the Ethics Committee. The study was performed in accordance with Directive 2010/ 63/EU of the European Parliament and of the Council of 22 September 2010 on the protection of animals used for scientific purposes, Chapter I, Article 1, point 5(b). Research was also approved by the Scientific Research Committee of the Department and Clinic of Animal Surgery at the University of Life Sciences in Lublin (\#1/ 2018) concerning non-experimental clinical patients.

All samples were collected from dogs prior to treatment. Before the bacteriological examination, the patients were not administered any topical or systemic drugs.

The samples were collected from the conjunctival sac after grasping the lower eyelid to reveal the conjunctiva of the lower eyelid and third eyelid using a sterile swab (Meus s.r.i., Piove di Sacco, Italia). The sample was collected by moving the swab towards the conjunctival sac, avoiding contact with the palpebral margin and eyelashes, after which it was inoculated onto transport medium and transported for analysis within $20 \mathrm{~min}$ at $4{ }^{\circ} \mathrm{C}$. The swabs were collected from the right and left eye of each dog without local anaesthesia.

Bacterial strains were isolated (about 80 isolates) on two types of media: mannitol agar (Chapman medium, BTL, PL) and Columbia blood agar with $5 \%$ sheep blood (BTL, PL) under aerobic conditions at $37^{\circ} \mathrm{C}$ for $24 \mathrm{~h}$. The cultures were incubated in TSB broth (BTL, PL) at $37^{\circ} \mathrm{C}$ for $24 \mathrm{~h}$ to obtain optimum growth of pure strains. Phenotypic identification of Staphylococcus spp. isolates was carried out by means of Gram staining and biochemical commercial API STAPH tests. Molecular identification was carried out by MALDI-TOF MS mass spectrometry [23].

Measurements were performed with an UltrafleXtreme MALDI-TOF mass spectrometer (Bruker, Germany) equipped with a $1000 \mathrm{~Hz}$ neodymium-doped yttrium aluminium garnet (Nd:YAG) laser. For this method, single bacterial colonies grown on agar were re-suspended in $1.2 \mathrm{~mL}$ of $75 \%$ ethanol. After centrifugation at 13,000 $g$ for $2 \mathrm{~min}$ at $20^{\circ} \mathrm{C}$ and removal of the supernatant, cells were extracted with $50 \mu \mathrm{L}$ of formic acid (Sigma-Aldrich, Poland) and $50 \mu \mathrm{L}$ of acetonitrile (Sigma-Aldrich, Poland). After centrifugation, each of the samples was transferred onto a spot of a 384 MTP AnchorChip TF stainless steel MALDI target plate (Bruker, Germany). Then the bacterial sample was overlaid with $1 \mu \mathrm{l}$ of matrix solution containing $10 \mathrm{mg} / \mathrm{ml} \mathrm{HCCA} \mathrm{(a-cyano-4-}$ hydroxycinnamic acid, Sigma-Aldrich, Poland) resolved in 50\% acetonitrile and 2.5\% TFA (trifluoroacetic acid, Sigma-Aldrich, Poland) and air-dried. The MALDI plate was then introduced into the spectrometer for automated measurement and data interpretation. Prior to the analyses, calibration was performed with a bacterial test standard (Bruker, Germany) containing extract of Escherichia coli DH5 alpha [24, 25]. The mass spectra were processed with the MALDI Biotyper 3.0 software package (Bruker, Germany), containing 3995 reference spectra corresponding to different types of bacteria.

The results were shown as the top 10 identification matches with confidence scores ranging from 0.00 to 3.00. A $\log$ (score) $<1.70$ does not allow for reliable identification, a log (score) between 1.70 and 1.99 allows identification to the genus level, a log (score) between 2.00 and 2.29 means highly probable identification at the genus level and probable identification at the species level, and a $\log$ (score) $>2.30$ indicates highly probable identification at the species level (according to the manufacturer's instructions).

A catalase test the one of biochemical tests that commonly used to differentiate $S$. aureus from coagulasenegative staphylococci for a reason of virulence, was carried out to detect pathogenic Staphylococcus spp. strains. The test is performed by flooding an agar slant or broth culture with several drops of $3 \%$ hydrogen peroxide. Catalase-positive cultures bubble at once [26].

\section{Evaluation of the antibiotic resistance of the strains}

The strains were examined to determine the profile of resistance to selected antimicrobial substances of various classes, i.e. amoxicillin (25); amoxicillin-clavulanic acid (30 $\mu \mathrm{g})$, ampicillin $(10 \mu \mathrm{g})$, amikacin $(30 \mu \mathrm{g})$, ciprofloxacin $(5 \mu \mathrm{g})$, clindamycin $(2 \mu \mathrm{g})$; enrofloxacin $(30 \mu \mathrm{g})$, erythromycin $(15 \mu \mathrm{g})$, gentamicin $(10 \mu \mathrm{g})$, kanamycin $(30)$, methicillin $(10 \mu \mathrm{g})$ lincomycin/spectinomycin $(109 \mu \mathrm{g})$, vancomycin $(30 \mu \mathrm{g})$, oxacillin $(1 \mu \mathrm{g})$ polymyxin $(300 \mu \mathrm{g})$, sulfamethoxazole-trimethoprim $(25 \mu \mathrm{g})$, tobramycin $(10 \mu \mathrm{g})$ and tetracycline $(30 \mu \mathrm{g})$, in accordance with CLSI recommendations for these antibiotics. The antibiotic resistance profiles of the strains were determined by the disc-diffusion method on Mueller-Hinton agar (Oxoid Ltd) as described by CLSI 2017 [25] and EUCAST [27]. The MIC results were compared with values for $S$. aureus ATCC 25923. 


\section{Preparation of the bacteriophage suspension}

Bacteriophages specific for Staphylococcus strains were isolated and characterized in accordance with the procedure proposed by Han et al. [28], as modified by Marek et al. [29] Prior to further characterization, the phages were individually plaque-purified three times on agar plates. All of used phages were coming from our own collection and all phages were previously isolated from seawage.

Following $24 \mathrm{~h}$ incubation at $37^{\circ} \mathrm{C}$, the bacteriophages were collected from $0.7 \%$ agar from zones with complete lysis of bacteria (plaques) and transferred to $2 \mathrm{ml}$ of TSB broth. The whole was suspended in Tryptic soy broth (TSB), with the addition of $250 \mu \mathrm{L} 1 \mathrm{M} \mathrm{CaCl}_{2}, 250 \mu \mathrm{L} 1$ $\mathrm{M} \mathrm{MgSO}_{4}$ and $250 \mu \mathrm{L}$ of a $3 \mathrm{~h}$ culture of $\mathrm{S}$. aureus, and incubated in a shaker for $18 \mathrm{~h}$ at $37^{\circ} \mathrm{C}$ and $120 \mathrm{rpm}$. After centrifugation at 12,000 $\mathrm{xg}$ for $30 \mathrm{~min}$, chloroform was added to the supernatant to a final concentration of $2 \% \mathrm{v} / \mathrm{v}$. After vortexing for $5 \mathrm{~min}$, centrifugation $(5000$ $x g / 10 \mathrm{~min} / 20^{\circ} \mathrm{C}$ ), and filtration, the suspension was stored at $4{ }^{\circ} \mathrm{C}$ until further analysis.

In the next stage of the study, the lytic titres of the bacteriophages were determined by the double-layer agar method on Tryptic soy agar (TSA). The range of lytic activity against the pathogens as well as the $\mathrm{pH}$ tolerance of the phages was determined on double-layer agar plates according to Niu et al. [30] Morphological analysis of the bacteriophages was performed by transmission electron microscopy (TEM) using slides negatively stained with $2 \%$ uranyl acetate [31]. For comparison of phage morphology, a phage specific to $S$. aureus ATCC 25923 was used as a reference.

The bacteriophage lysate was concentrated by precipitation in polyethylene glycol (PEG) 8000 solution according to Chibani-Chennoufi et al. [32]. To this end, $6.5 \mathrm{~mL}$ of 20\% PEG $8000 \mathrm{NaCl}$ buffer was added to tubes containing a suspension of bacteriophages, which was then mixed on a vortex and incubated at $4{ }^{\circ} \mathrm{C}$ for $24 \mathrm{~h}$. Next, following centrifugation at $8500 \mathrm{xg} / 10 \mathrm{~min} / 4{ }^{\circ} \mathrm{C}$, the precipitate was suspended in a specified volume of TE buffer. Following centrifugation at $11,000 \times \mathrm{g} / 10$ $\min / 4{ }^{\circ} \mathrm{C}, 120 \mu \mathrm{L}$ of $20 \%$ PEG $8000 \mathrm{NaCl}$ was added to the suspension, which was then incubated at $4{ }^{\circ} \mathrm{C}$ for 1.5 h. After centrifugation at $13,000 x g / 10 \mathrm{~min} / 4{ }^{\circ} \mathrm{C}$ and removal of the supernatant, Tris-EDTA (TE) buffer was added to the precipitate again. The resulting suspension was extracted with an equal amount of chloroform, followed by vortexing for $30 \mathrm{~s}$ to remove residual polyethylene glycol. The concentrated suspension of bacteriophages was centrifuged at $4500 \times \mathrm{g} / 7 \mathrm{~min} / 4{ }^{\circ} \mathrm{C}$. The purification procedure was followed by dialysis of the bacteriophage lysate through a Pellicon membrane (1000 kDa, EMD Millipore) according to SzermerOlearnik and Boratynski [33].
The aqueous phase was collected, and following determination of the lytic titre, was stored at $4{ }^{\circ} \mathrm{C}$ until use as a component of eye drops.

The number of bacteriophage plaque-forming units (PFU) was determined by serial dilutions of the phage lysate suspended in the above-mentioned solution prepared for eye drops [34].

\section{Preparation of eye drops and assessment of their antibacterial efficacy in vitro}

Only phages with strong lytic titres $>10^{8} \mathrm{PFU} / \mathrm{mL}$ and with stabilized lytic properties were used to prepare eye drops. Eye drops were prepared using eight different solutions (Table 1).

Under aseptic conditions, the solids listed in Table 1 were dissolved in Aqua Pro Injectione (Baxter, PL). Depending on the composition of the formulation, glycerol was added and the $\mathrm{pH}$ of the solution was adjusted to 6.92-7.52 using $0.2 \mathrm{~N}$ sodium hydroxide solution. A suspension of bacteriophages was then added and supplemented with water where necessary to $100 \mathrm{~mL}$. The solutions were mixed and then filtered through a Schott G-5 glass filter.

The experimental phage formulations prepared in this manner were then placed in hermetically sealed $10 \mathrm{~mL}$ dark glass bottles and stored at $4-8{ }^{\circ} \mathrm{C}$ in a refrigerator. The $\mathrm{pH}$ of the solutions was measured with a CP-411 $\mathrm{pH}$-meter (Elmetron), and the osmotic pressure with a Trident $800 \mathrm{cL}$ osmometer. The percentage composition of each formulation is presented in detail in Table 1.

Of the eight eye drop variants, only those that did not significantly affect the viability and lytic titre of the bacteriophages specific for Staphylococcus spp. strains were used for further in vitro testing.

\section{Limulus Amebocyte lysate assay for endotoxins estimation}

For quantification of the cytotoxicity of bacterial endotoxins in all experimental eye drops, the Chromogenic Limulus Amebocyte Lysate (LAL, Lonza) test was performed. The procedure was carried out on pyrogen-free microplates according to the manufacturer's instructions.

Prior to analysis, the samples were diluted with Binding Buffer. First all samples were incubated on microassay plates overnight at room temperature with shaking. For this purpose, $50 \mu \mathrm{L}$ of sample was dispensed in duplicate in a 96-well flat-bottomed plate. The blank wells contained $50 \mu \mathrm{L}$ of water (LAL Reagent Water; Lonza) instead of sample. Then $50 \mu \mathrm{L}$ of LAL was added to all microplate wells. After $10 \mathrm{~min}$ of incubation at $37^{\circ} \mathrm{C}$, $100 \mu \mathrm{L}$ of pre-warmed substrate solution was mixed with each of the LAL-samples and incubated at $37^{\circ} \mathrm{C}$ for an additional $6 \mathrm{~min}$. The reaction was stopped with $100 \mu \mathrm{L}$ of stop reagent. If endotoxin was present in the sample, 
Table 1 The Percentage of Individual Experimental Variants of Eye Drops for Dogs with Bacterial Conjunctivitis

\begin{tabular}{|c|c|c|c|c|c|c|c|c|}
\hline \multirow[t]{2}{*}{ Components } & \multicolumn{8}{|c|}{ Formulations } \\
\hline & 1 & 2 & 4 & 7 & 8 & 9 & 10 & 12 \\
\hline The bacteriophages suspension $10^{-10} \mathrm{PFU} / \mathrm{mL}$ & $20.0 \% \mathrm{v}$ & $20.0 \% \mathrm{v}$ & $20.0 \% \mathrm{v}$ & $20.0 \% \mathrm{v}$ & $20.0 \% \mathrm{v}$ & $20.0 \% \mathrm{v}$ & $20.0 \% \mathrm{v}$ & $20,0 \%$ v \\
\hline Boric acid & $1.1 \% \mathrm{w}$ & - & - & - & - & - & - & - \\
\hline Sodium tetraborate & $0.29 \% \mathrm{w}$ & - & - & - & - & - & - & - \\
\hline Sodium chloride & $0.29 \% \mathrm{w}$ & $0.9 \% \mathrm{w}$ & $0.9 \% \mathrm{w}$ & $0.9 \% \mathrm{w}$ & - & - & - & - \\
\hline Mannitol & - & - & - & - & $5.0 \% \mathrm{w}$ & - & - & - \\
\hline $85 \%$ Glycerol & - & - & - & - & - & $2.42 \% \mathrm{v}$ & $2.42 \% \mathrm{v}$ & $3,97 \% \vee v$ \\
\hline Disodium EDTA & - & $0.05 \% \mathrm{w}$ & $0.05 \% \mathrm{w}$ & - & $0.05 \% \mathrm{w}$ & - & $0.05 \% \mathrm{w}$ & $0,05 \% \mathrm{w}$ \\
\hline Benzalkonium chloride & - & - & $0.01 \% \mathrm{w}$ & $0.01 \% \mathrm{w}$ & - & - & - & $0,01 \% \mathrm{w}$ \\
\hline $0.2 \mathrm{M} \mathrm{NaOH}$ & - & q.s. to 7.05 & q.s. to 7,07 & q.s. to 6,93 & q.s. to 6.92 & - & q.s to 7.02 & q.s to 6,92 \\
\hline Water for injection & to $100 \% \mathrm{v}$ & to $100 \% \mathrm{v}$ & to $100 \% \mathrm{v}$ & to $100 \% \mathrm{v}$ & to $100 \% \mathrm{v}$ & to $100 \% \mathrm{v}$ & to $100 \% \mathrm{v}$ & to $100 \% \mathrm{v}$ \\
\hline $\mathrm{pH}$ & 7.52 & 7.05 & 7.07 & 6.93 & 6.92 & 7.06 & 7.02 & 6,92 \\
\hline Osmotic pressure mOsm/kg & 290 & 280 & 285 & 286 & 292 & 310 & 287 & $517 \mathrm{mOsm} / \mathrm{kg}$ \\
\hline
\end{tabular}

a yellow colour appeared. The absorbance was determined with a BioRad 680 model microplate reader at a wavelength of $405-410 \mathrm{~nm}$. The concentration of endotoxins was calculated from a standard curve and shown in European units (EU) [33].

Every 7 days the phage compositions were tested for antibacterial activity and lytic titre stability by the double-layer agar plate method [32].

The stability of the antibacterial titre was evaluated for preparations stored in sealed bottles as well as after opening and reclosing. The efficacy of the eye drops against Staphylococcus spp. strains was determined in in vitro conditions.

\section{Results}

All dogs in the study had conjunctivitis characterized by conjunctival hyperthermia and purulent ocular discharge. The clinical signs of the disease were conjunctival hyperaemia and purulent discharge from the conjunctival sac. Swabs collected from dogs confirmed suffering from purulent conjunctivitis, which in 35 cases was associated with keratoconjunctivitis sicca and in 48 cases with follicular inflammation of the third eyelid, while in 18 cases it was primary bacterial conjunctivitis. In 19 dogs, purulent inflammation was accompanied by chronic superficial keratitis. The dogs had no systemic diseases.

In our study, we isolated the bacteria towards Staphylococcus spp. The tests confirmed the occurrence of Staphylococcus spp. strains as etiological agents of bacterial conjunctivitis in the animals. In total, 80 Staphylococcus spp. strains were isolated.

The Staphylococcus species represented in the highest numbers was $S$. epidermidis $(n=45)$, followed by $S$. aureus $(n=25)$, while $S$. pseudintermedius was the least numerous $(n=10)$, as confirmed by both biochemical tests and MALDI TOF mass spectrometry.

MALDI TOF mass spectrometry analysis confirmed the high percentage of strain identification at the species level. The results are shown in Table 2 .

Analysis of the antibiotic resistance of the bacterial strains showed that a high percentage of strains were resistant to more than one antibiotic. All strains tested were resistant to erythromycin, tetracycline and oxacillin, and all S. pseudintermedius strains were also resistant to lincomycin/spectinomycin and gentamicin (Table 3). A high level (63.75-76.25\%) of multi-drug resistance was observed, i.e. resistance to least 3 of the 18 antibiotics (Table 3). Additionally, $100 \%$ of S. aureus strains were shown to be resistant to ampicillin and kanamycin. It is worrying that among the isolates tested, 3 strains of $S$. aureus showed resistance to vancomycin (Table 3). However, these results for vancomycin were obtained only by the disc-diffusion method, while the MIC test did not show resistance to vancomycin.

The highest percentage of strains susceptible to the antibiotics was observed for $S$. pseudintermedius, in which $100 \%$ of strains were susceptible to 6 of 18 antibiotics: amoxicillin/clavulanic acid, polymyxin, clindamycin, vancomycin, ciprofloxacin and methicillin. S. epidermidis strains were $100 \%$ susceptible to 4 antibiotics, i.e. lincomycin/spectinomycin, polymyxin B, vancomycin, and ciprofloxacin, while $100 \%$ of $S$. aureus strains were susceptible only to lincomycin/spectinomycin and polymyxin B. It should be emphasized that all three staphylococcal species were $100 \%$ susceptible to polymyxin B (Table 3 ).

We obtained 10 bacteriophages specific for pathogenic Staphylococcus spp. isolated from dogs. All tested phages were from our own collection and were isolated from water samples. All information about the phages was 
Table 2 Mean log (score) results of MALDI-TOF MS analysis of Staphylococcus spp. isolated from dogs with bacterial conjunctivitis

\begin{tabular}{|c|c|c|c|c|c|}
\hline \multirow{2}{*}{$\begin{array}{l}\text { Log } \\
\text { (score) }\end{array}$} & \multirow[t]{2}{*}{ Description } & \multirow[t]{2}{*}{ Symbol } & \multicolumn{2}{|c|}{ Bacterial species } & \multirow[b]{2}{*}{$\begin{array}{l}\text { S. } \\
\text { epidermidis } \\
\mathrm{n}=45\end{array}$} \\
\hline & & & $\begin{array}{l}\text { S. } \\
\text { aureus } \\
\mathrm{n}=25\end{array}$ & $\begin{array}{l}\text { S. pseudintermedius } \mathrm{n}= \\
10\end{array}$ & \\
\hline $\begin{array}{l}2.300- \\
3.000\end{array}$ & Highly probable identification at the species level & ++++ & 12 & 7 & 39 \\
\hline $\begin{array}{l}2.000- \\
2.299\end{array}$ & $\begin{array}{l}\text { Highly probable genus identification and probable species } \\
\text { identification }\end{array}$ & +++ & 7 & 2 & 4 \\
\hline $\begin{array}{l}1.700- \\
1.999\end{array}$ & Identification to the genus level & ++ & 4 & 1 & 2 \\
\hline$<1.700$ & Does not allow for reliable identification & + & 1 & 0 & 0 \\
\hline
\end{tabular}

included in Patent Applications P.427797 and $427798[35,36]$. The results of transmission electron microscopy (TEM) analysis showed that most of the Staphylococcus spp. phages under study belonged to the Myoviridae family, based on icosahedral heads with sizes ranging from 64 to $95 \mathrm{~nm}$ and long contractile tails from 190 to $250 \mathrm{~nm}$ in the extended state (Fig. 1). The lytic titres were estimated as $10^{6}-10^{10}$ $\mathrm{PFU} / \mathrm{mL}$. Most of the phages expressed lytic properties against more than $80 \%$ of tested Staphylococcus spp. strains in our collection, but only 5 phages (W15, W17, W33, W31 and W36) showed long-term stability in antibacterial activity against all examined strains. These phages were used as a cocktail in the eye drops (Table 4).

Only three of the variants of eye drop solutions, nos. 4, 7 and 12, had no negative impact on the bacteriophages (destruction or significant reduction of lytic titre). For this reason, these solutions were selected for further analysis, to assess their bactericidal efficacy against Staphylococcus spp. test strains obtained from dogs with symptoms of bacterial conjunctivitis. Based on their antibacterial properties and the time during which a high antibacterial titre persisted, eye drop solutions 4, 7 and 12 were confirmed to be highly effective (see results in Fig. 2). Figure 2 presents examples of the

Table 3 Antibiotic resistance profiles of Staphylococcus species isolated from dogs with bacterial conjunctivitis

\begin{tabular}{|c|c|c|c|c|c|c|c|}
\hline \multirow[t]{3}{*}{ Antibiotic } & \multicolumn{6}{|c|}{ Numbers and \% of resistant and susceptible bacteria } & \multirow{3}{*}{$\begin{array}{l}\text { Total } \% \\
\text { of } \\
\text { resistance }\end{array}$} \\
\hline & \multicolumn{2}{|c|}{ S. epidermidis $(n=45)$} & \multicolumn{2}{|c|}{ S. aureus $(n=25)$} & \multicolumn{2}{|c|}{ S. pseudintermedius $(n=10)$} & \\
\hline & $\mathbf{R}$ & $\mathrm{S}$ & $\mathbf{R}$ & $\mathrm{S}$ & $\mathbf{R}$ & $\mathrm{S}$ & \\
\hline Amoxicillin AML25 & 26.6 & 73.4 & 76 & 24 & 20 & 80 & 41.5 \\
\hline Amoxicillin/clavulanic acid AMC30 & 6.6 & 93.4 & 24 & 76 & 0 & 100 & 11.25 \\
\hline Ampicillin AMP10 & 8.9 & 91.1 & 100 & 0 & 20 & 80 & 38.75 \\
\hline Amikacin AN 30 & 71.1 & 28.9 & 60 & 40 & 40 & 60 & 63.75 \\
\hline Enrofloxacin ENR5 & 22.2 & 77.8 & 8 & 92 & 30 & 70 & 18.75 \\
\hline Lincomycin/spectinomycin LS109 & 0 & 100 & 0 & 100 & 100 & 0 & 12.5 \\
\hline Sulfamethoxazole/trimethoprim SXT25 & 80 & 20 & 72 & 28 & 70 & 30 & 76.25 \\
\hline Polymyxin PB 300 & 0 & 100 & 0 & 100 & 0 & 100 & 0 \\
\hline Erythromycin E 15 & 100 & 0 & 0 & 0 & 100 & 0 & 100 \\
\hline Gentamicin CN 10 & 15.5 & 84.5 & 12 & 88 & 100 & 0 & 25 \\
\hline Tetracycline TE & 97.7 & 2.3 & 100 & 0 & 100 & 0 & 100 \\
\hline Clindamycin DA 2 & 6.66 & 93.34 & 52 & 48 & 0 & 10 & 20 \\
\hline Oxacillin OXA 1 & 10 & 0 & 100 & 0 & 100 & 0 & 100 \\
\hline Vancomycin VA 30 & 0 & 100 & 12 & 88 & 0 & 10 & 3.75 \\
\hline Tobramycin TOB 10 & 55.5 & 44.5 & 36 & 64 & 70 & 30 & 51.25 \\
\hline Kanamycin K 30 & 66.7 & 33.3 & 100 & 0 & 40 & 60 & 73.75 \\
\hline Ciprofloxacin CIP 5 & 0 & 100 & 4 & 96 & 0 & 100 & 1.25 \\
\hline Methicillin MEL 10 & 2.2 & 97.8 & 12 & 88 & 0 & 100 & 32.5 \\
\hline
\end{tabular}



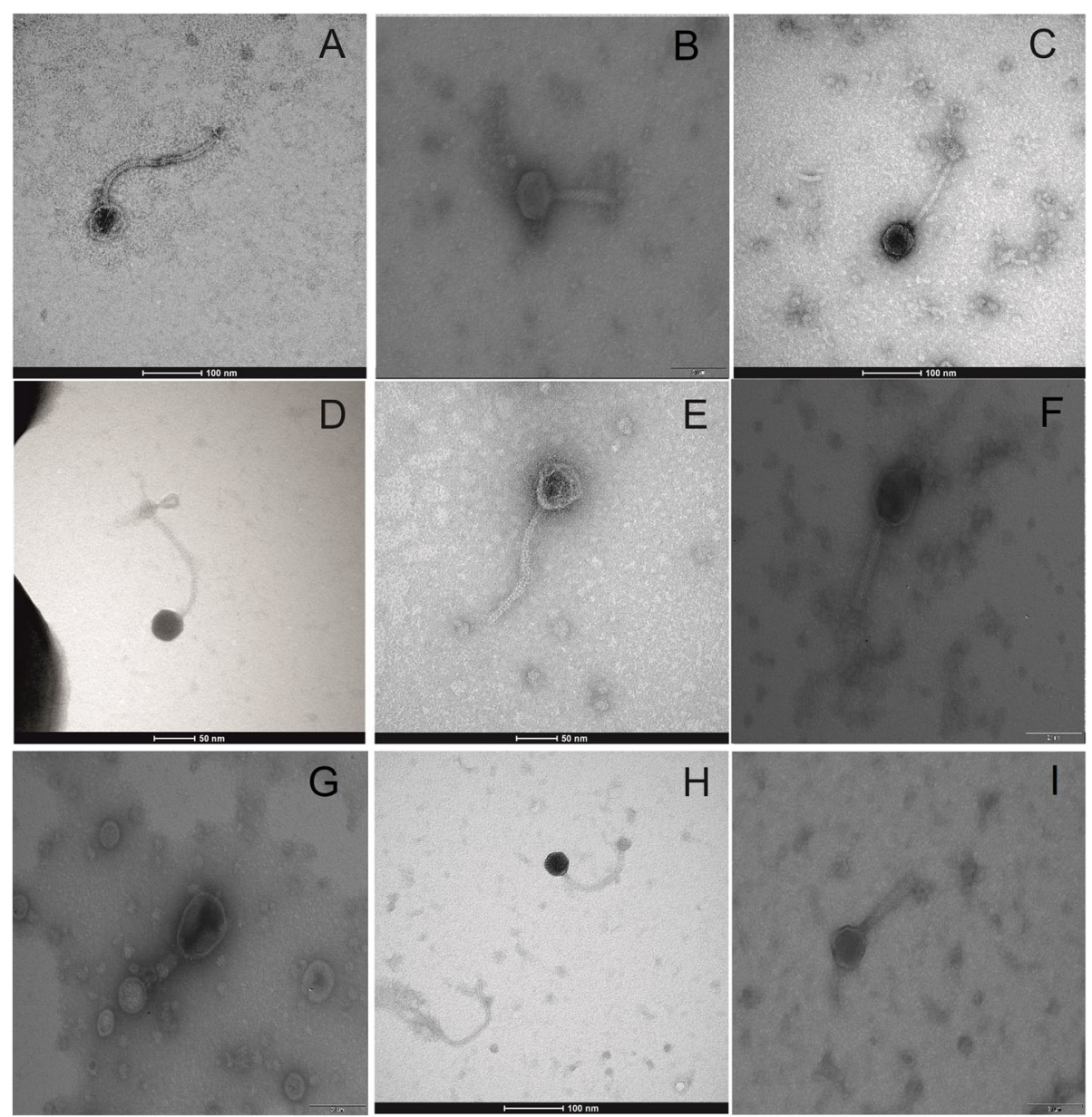

H
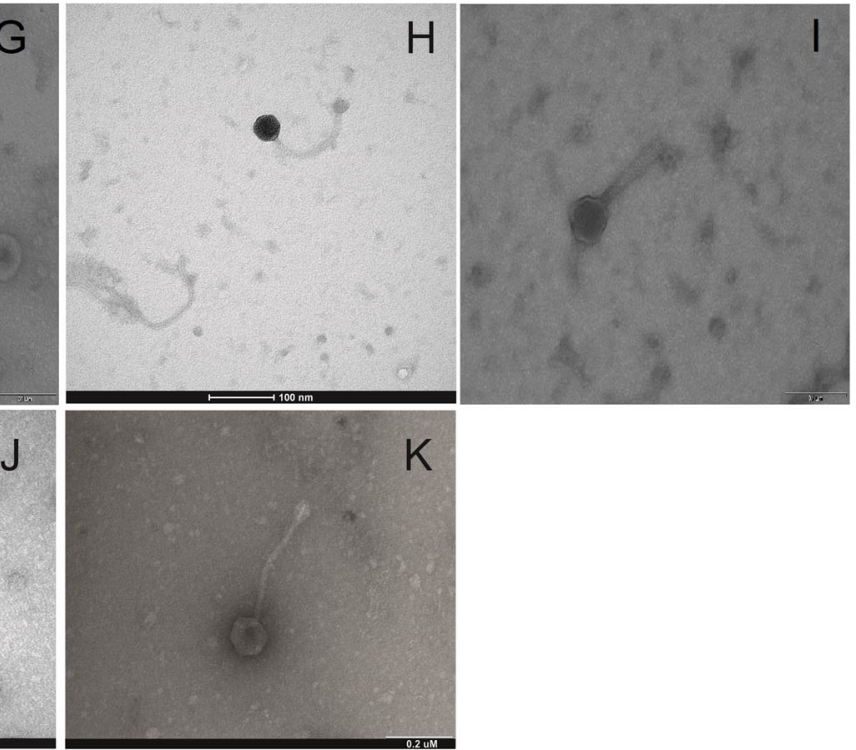

Fig. 1 Negative-stained electron micrographs of bacteriophages induced in isolates of Staphylococcus spp. Legend: Myoviridae and Siphoviridae phages: A - phage no. W28, B - W15, C - W36, D - W29B, E - W29, F - W17, G - W31, H - W1, I - W33, J - W27; K- Reference Myoviridae phage specific for S. aureus ATCC 25923

antibacterial effect of the experimental drops, but only for dilutions resulting in a complete lysis zone in in vitro conditions. The eye drops remained active, as evaluated by storing the suspension at $4-8^{\circ} \mathrm{C}$ in unopened dark bottles, for nearly 6 weeks.

The level of endotoxin in the eye drop solutions estimated in the Limulus amoebocyte lysate assay was below $50 \mathrm{EU} / \mathrm{mL}$.

The results confirmed the significant antibacterial effect of the experimental eye drops containing bacteriophages. All bacterial strains were destroyed after the drops were applied to the bacterial cell cultures on double-layer agar plates. Formulations 7 and 12 maintained their constant antibacterial titre of $\geq 10^{8} \mathrm{PFU} / \mathrm{mL}$ for 21 days after the bottles had been opened and closed again, The corresponding period for formulation no. 4 was shorter, at 14 days, after which the lytic titre fell significantly and was insufficient to ensure elimination of bacteria in vitro. The bottles with the ophthalmic solutions were stored at 4$8^{\circ} \mathrm{C}$. We did not detect any changes in the $\mathrm{pH}$ of the ophthalmic solutions, which corresponded to pharmacopoeial values (the $\mathrm{pH}$ range for eye drops according to 
Table 4 Types, titres and lytic activity spectrum of bacteriophages specific for Staphylococcus spp. isolates obtained from dogs with bacterial conjunctivitis

\begin{tabular}{|c|c|c|c|c|}
\hline $\begin{array}{l}\text { Phage } \\
\text { no. }\end{array}$ & Morphology & Bacterial host & $\begin{array}{l}\text { Lytic titre } \\
\text { PFU }\end{array}$ & $\begin{array}{l}\text { Spectrum of lytic activity: total percentage of Staphylococcus spp. strains } \\
\text { undergoing lysis }\end{array}$ \\
\hline W28 & Siphoviridae & S. aureus & $10^{10}$ & $68(85 \%)$ \\
\hline W15 & Myoviridae & S. aureus & $10^{10}$ & $80(100 \%)$ \\
\hline W36 & Myoviridae & S. epidermidis & $10^{9}$ & $80(100 \%)$ \\
\hline W29B & Siphoviridae & S. epidermidis & $10^{8}$ & $72(90 \%)$ \\
\hline W29 & Siphoviridae & $\begin{array}{l}\text { S. } \\
\text { pseudintermedius }\end{array}$ & $10^{6}$ & $68(85 \%)$ \\
\hline W17 & Myoviridae & S. epidermidis & $10^{10}$ & $80(100 \%)$ \\
\hline W31 & Myoviridae & S. aureus & $10^{9}$ & $80(100 \%)$ \\
\hline W33 & Myoviridae & $\begin{array}{l}\text { S. } \\
\text { pseudintermedius }\end{array}$ & $10^{10}$ & $80(100 \%)$ \\
\hline$\varphi \mathrm{W} 1$ & Siphoviridae & S. epidermidis & $10^{9}$ & $80(100 \%)$ \\
\hline$\varphi \mathrm{W} 27$ & Siphoviridae & S. aureus & $10^{7}$ & 75 (93.7\%) \\
\hline
\end{tabular}

Pharmacopeia European X, Ph. Eur is 3.5-8.5), while the osmotic pressure slightly decreased, but was still within ocular tolerance up to the end of the study (United States Pharmacopeia USP XIII).

Patent applications were submitted for two phage formulations in the form of eye drops to the Patent Office of the Republic of Poland in 2018 - application nos. P.427797 and P.427797 [35, 36].

\section{Discussion}

The results of the research confirmed a high percentage share of strains of the genus Staphylococcus spp. as etiological agents of bacterial conjunctivitis in dogs. Particularly noteworthy is the high number (45) of strains of the species S. epidermidis, representing over $56 \%$ of all bacterial isolates. The number of $S$. aureus isolates was 25 , accounting for $31 \%$. The results differ from those reported by Junior et al. [37], in which the percentage of Staphylococcus strains isolated from cases of bacterial conjunctivitis in dogs was $>66 \%$, of which $S$. epidermidis isolates constituted only $6 \%$. S. aureus accounted for $25 \%$ of strains, similar to the percentage obtained in our study (31\%). However the \% of the prevalence of S. epidermidis in dogs was similar like in the study of GómezSanz et al. [38], where the total \% of prevalence of S. epidermidis was $66 \%$. The high percentage of S.epidermidis strains observed in our as well as the cited research may be result from the presence of specific isolates in a given area, region or environment. However in case of the rest Staphylococcus spp. strains the obtained results were very similar to cited authors.

Our research confirmed the high rate of resistance of Staphylococcus spp. strains to more than one antibiotic - in many cases to a third of the antibiotics used in the study.

The resistance of the test strains to selected antibiotics observed in the present study supports results obtained by other authors, such as Junior et al. [37] , who reported $100 \%$ resistance to sulphonamide and $91.67 \%$ resistance to tetracycline for $S$. aureus, and $75 \%$ resistance to tetracycline and ceftriaxone for S. intermedius. The latest research indicates a significant upward trend in resistance to $\beta$-lactams, including oxacillin, as well as erythromycin and tetracycline [38].

It is concerning that $100 \%$ of the tested isolates were resistant to erythromycin, which in addition to fluoroquinolones and chloramphenicol is commonly used to treat bacterial conjunctivitis in dogs [4]. Infections caused by Gram-negative rods are additionally treated with aminoglycoside antibiotics [39].

The results of our study, showing a high percentage of resistant bacteria, confirm the need to look for new therapeutic solutions as alternatives to antibiotics to eliminate the etiological agents of bacterial conjunctivitis in dogs. A positive result observed in the presented own studies is the $100 \%$ sensitivity of all tested Staphylococcus spp. isolates to Polymixin B.

The five Myoviridae phages (W15, W17, W33, W31 and W36) used in the present study as components of experimental eye drops were selected for their wide spectrum of infectivity and lytic nature. According to some authors, virulent bacteriophages of the Myoviridae family specific for Staphylococcus spp. may be better suited for phage therapy due to their lack of or highly restricted capacity for horizontal gene transfer, as in the case of lysogenic phages. Other phages like Siphoviridae family, are mostly the temporary phages and can be reservoirs of antibiotic resistance genes that can be transferred to bacteria on during the lysogeny process in bacteria [20].

However, as with antibiotics, bacteria have the potential to acquire resistance to bacteriophages. Bacteria could induce resistance mechanisms, through a change 


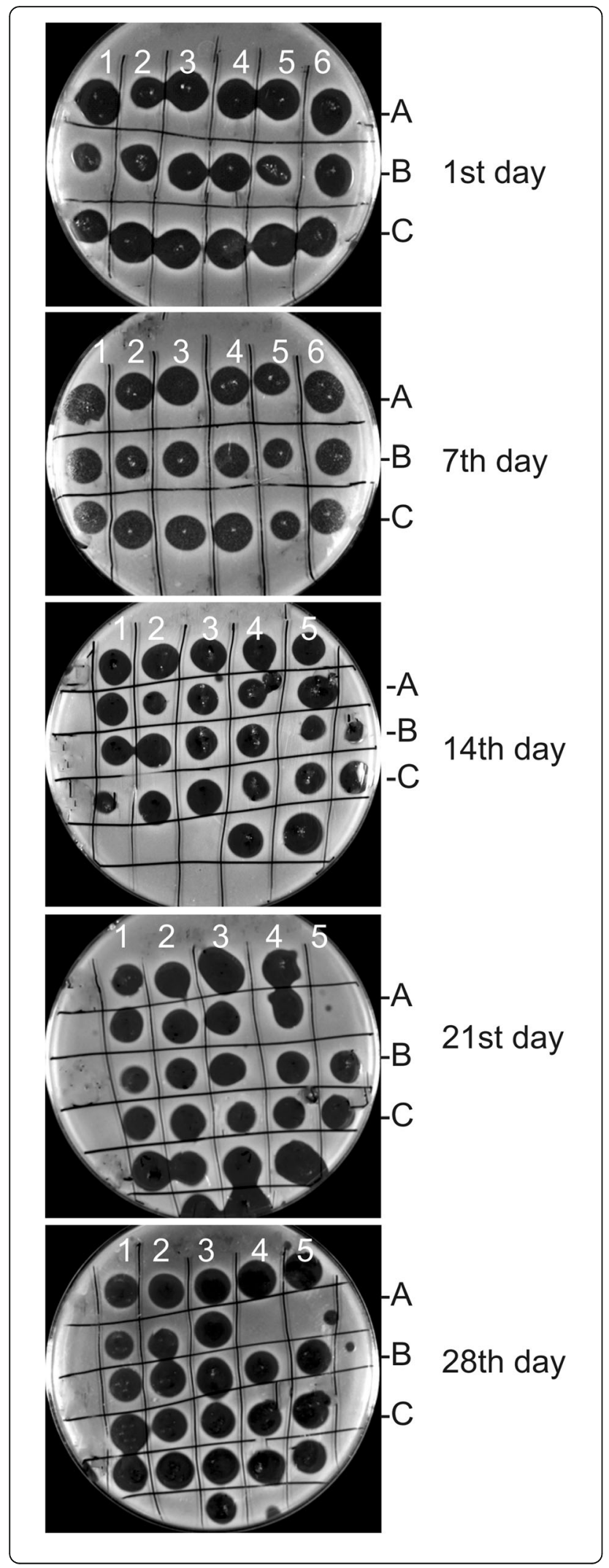

Fig. $\mathbf{2}$ In vitro lytic activity of experimental eye drops against selected strains of Staphylococcus spp. Legend: a Experimental eye drops solution no 4; b Experimental eye drops solution no 7; C experimental eye drops solution no 12Arabic numbers 1 to 6 refer to dilutions of experimental phage drops [1- stock solution, 2dilution 1:2, 3- dilution 1:4, 4- dilution 1:8; 5- dilution 1:16; 6dilution 1:32]

or loss of surface receptors, secretion of substances that prevent phage adhesion to the bacterial cells, activation of measures for blocking phage DNA injection into the cell, or inhibition of phage replication and release [40]. According to a review by Rohde et al. [41], the mechanism of antibacterial resistance developed by phages is mainly observed in in vitro studies. For example, it is correlated with the appearance of new anti-phage spacers in CRISPR loci (clustered regularly interspaced short palindromic repeats). Also, because the total number of bacteriophages in the environment significantly exceeds the number of bacteria, thus far no such significant increase in bacteria resistant to phages has been observed.

The experimental phage preparations developed in the study in the form of eye drops exhibited $100 \%$ efficacy in vitro against all tested Staphylococcus isolates. Particularly noteworthy is the long duration of activity and constant lytic titre of preparations 7 and 12, both after the bottle had been opened (min. 21 days) and in the case of hermetically sealed packaging (min. 28 days) and refrigeration at $4-8^{\circ} \mathrm{C}$. This is advantageous, as the shelf life of antibiotic eye drops in a pharmacy without a preservative is up to $24 \mathrm{~h}$ after opening, and up to 10 days with the addition of a preservative. Examples of this type of preparation used in the treatment of eye diseases include compounded eye drops containing detreomycin or gentamicin. Hence the experimental phage preparations in the form of eye drops have a significantly longer shelf life, which is an argument in their favour.

Given the high sensitivity of the eye to damage and external factors, eye drops must meet several requirements so as not to cause irritation or sensitization of the eye. They must be sterile, isotonic with tear fluid, and have a $\mathrm{pH}$ in the range of 3.5-8.5. To meet these requirements, eye drops may contain auxiliary substances such as isotonizing and buffering agents, preservatives, and viscosity modifiers. These substances must not exert their own pharmacological or irritating effects in the amounts used. In the experimental eye drops used in this study, preservatives were used to stabilize the bacteriophages and extend the shelf-life of the preparations. The most widely used preservative in eye drops is benzalonium chloride, in concentrations ranging from 0.005 to $0.2 \%$. BAK toxicity depends on the amount administered daily, the duration of the treatment, and its concentration in the solution. However, at a concentration of $0.01 \%$, 
short-term administration of this agent should not be irritating, as confirmed in many studies [42, 43].

Despite the 100\% antibacterial effect demonstrated in vitro, the results represent only the first stage of research and require continuation as experimental therapy in vivo, which will be the subject of further study.

\section{Conclusions}

The $100 \%$ antibacterial effect of the experimental eye drops containing a mixture of five phages specific for Staphylococcus spp. strains isolated from dogs with symptoms of bacterial conjunctivitis indicates that research could be undertaken on the use of bacteriophages to treat infections caused by Staphylococcus spp. strains in companion animals. If positive clinical effects are obtained in animals, the results can be used in applied research as potential components of antibacterial preparations for humans and animals, available for use in national and international studies. It is worth emphasizing the innovative nature of the research aimed at finding alternative solutions for eliminating multi-drug resistant pathogens.

\section{Abbreviations}

$\mathrm{CaCl}_{2}$ : Calcii chloridum; EDTA: Ethylenediaminetetraacetic acid; HCCA: Acyano-4-hydroxycinnamic acid; LAL: Limulus Amoebocyte Lysate; $\mathrm{MgSO}_{4}$ : Magnesium sulphate; MIC: Minimum inhibitory concentration MRSA: Methicillin-resistant Staphylococcus aureus; NaCl: Sodium chloride; PEG: Polyethylene glycol; PFU: Plaque-forming unit; TE: Tris EDTA Buffer; TEM: Transmission electron microscopy; TSA: Tryptic Soy Agar; TSB: Tryptic Soy Broth; $\mu \mathrm{L}$ : Microlitre

\section{Acknowledgements}

Not applicable.

\section{Conflict of interests}

The authors have no potential conflicts of interest with respect to the research, authorship, and/or publication of this article.

\section{Prior publication}

The data have not previously been published.

\section{Authors' contributions}

$R U C, I B$ and $M D$ - the conception of study, writing the manuscript, coordination the study and analysis of results. KS and EP - responsible for pharmaceutical evaluation of the eye drop solution. AN, EP, DSP, AM, AP, AW - participated in the study (collection of material, phage isolation and identification, results). The authors read and approved the final manuscript.

\section{Funding}

The authors received no financial support for the research, authorship, and/ or publication of this article.

\section{Availability of data and materials}

The datasets used and/or analysed in the study are available from the first and corresponding author on reasonable request. Some of the materials are available as patent applications UPRP P.427797 and UPRP P.427797 (2018).

\section{Ethics approval and consent to participate}

Not Applicable.

\section{Consent for publication}

Not applicable.

\section{Competing interests}

All authors of this manuscript are also co-authors of the obtained patents for eye drops No. P.427797 and 427,798 and declare no competing of interests. Also all authors have agreed to publish this article.

\section{Author details}

'SubDepartment of Veterinary Prevention and Avian Diseases, Institute of Biological Bases of Animal Diseases, Faculty of Veterinary Medicine, University of Life Sciences Lublin, Lublin, Poland. 'Department and Clinic of Animal Surgery, Faculty of Veterinary Medicine, Lublin, Poland. ${ }^{3}$ Department of Applied Pharmacy, Medical University of Lublin, Lublin, Poland.

Received: 8 June 2020 Accepted: 22 October 2020

Published online: 04 November 2020

\section{References}

1. Mouney MC, Stiles J, Townsend WM, Guptill L, Weese JS. Prevalence of methicillin-resistant staphylococcus spp. in the conjunctival sac of healthy dogs. Vet Ophthalmol. 2015;18(2):123-6

2. Featherstone $\mathrm{HJ}$, Heinrich $\mathrm{C}$. Ophthalmic examination and diagnostics. In: Gellat KN, et al., editors. Veterinary ophthalmology. 5th ed. Ames: Blackwell Publishing; 2013. p. 533-613.

3. Gelatt K, Gilger B, Kern T. Vet Ophthalmol. Vol. 2. 5th ed. Ames: WileyBlackwell; 2013. p. 912-44.

4. Martin CL. Ophthalmic disease in veterinary medicine. London: Manson Publishing; 2005. p. 401-70.

5. Balicki I, Radziejewski K, Bielecki W. Evaluation of corneal and conjunctival epithelium with use of impression cytology in mix-breed dogs diagnosed with keratoconjunctivitis sicca. Bull Vet Inst Pulawy. 2011;55:493-9.

6. Bauer G, Spiess BM, Lutz H. Exfoliative cytology of conjunctiva and cornea in domestic animals: a comparison of four collecting techniques. Vet Comp Ophthalm. 1996;6:181-6.

7. Perazzi A, Bonsembiante F, Gelain ME, Patruno M, Di lorio E, Migliorati A, et al. Cytology of the healthy canine and feline ocular surface: comparison between cytobrush and impression technique. Vet Clin Pathol. 2017;46:164-71.

8. Furiani N, Scarampella F, Martino PA, Panzini I, Fabbri E, Ordeix L. Evaluation of the bacterial microflora of the conjunctival sac of healthy dogs and dogs with atopic dermatitis. Vet Derm. 2011;22:490-6.

9. Whitley RD. Canine and feline primary ocular bacterial infections. Vet Clin North Am Small Anim Pract. 2000;30:1151.

10. Balicki I, Radziejewski K, Silmanowicz P. Studies on keratoconjunctivitis sicca incidence in crossbred dogs. Pol J Vet Sci. 2008;11:353-8.

11. Maggs DJ, Miller PE, Ofri R. Slatter's fundamentals of veterinary ophthalmology. 5th ed. St. Louis: Elsevier; 2013. p. 140-58.

12. Baeyens V, Felt-Baeyens $O$, Rougier S, Pheulpin S, Boisramé B, Gurny R. Clinical evaluation of bioadhesive ophthalmic drug inserts (BODI) for the treatment of external ocular infections in dogs. J Control Release. 2002;85:163-8.

13. Raygada JL, Levine DP. Methicillin-resistant Staphylococcus aureus: a growing risk in the hospital and in the community. Am Health Drug Benefits. 2009;2:86-95

14. Lakhundi S, Zhang K Methicillin-resistant Staphylococcus aureus: molecular characterization, evolution, and epidemiology. Clin Microbiol Rev. 2018;31:e00020-18.

15. Szymanek-Majchrzak K, Mlynarczyk A, Mlynarczyk G. Characteristics of glycopeptide-resistant Staphylococcus aureus strains isolated from inpatients of three teaching hospitals in Warsaw, Poland. Antimicrob Resist Infect Control. 2018;7:105.

16. Prestinoci F, Pezzotti P, Pantosti A. Antimicrobial resistance: a global multifaceted phenomenon. Pathog Glob Health. 2015;109:309-18.

17. Abata'ngelo V, Peressutti Baccil N, Boncompain CA, Amadio AA, Carrasco S, Sua'rez CA, et al. Broad-range lytic bacteriophages that kill Staphylococcus aureus local field strains. PLOSOne. 2017;12:e0181671.

18. Batinovic S, Wassef F, Knowler SA, Rice DTF, Stanton CR, Rose J, et al. Bacteriophages in natural and artificial environments. Pathogens. 2019;8:100.

19. Keen EC, Dantas G. Close encounters of three kinds: bacteriophages, commensal bacteria, and host immunity. Trends Microbiol. 2018;26:943-54.

20. Dec M, Wernicki A, Urban-Chmiel R. Efficacy of experimental phage therapies in livestock. Anim Health Res Rev. 2020:1-15. https://doi.org/10. 1017/S1466252319000161.

21. Loessner MJ. Bacteriophage endolysins - current state of research and applications. Curr Opin Microbiol. 2005;8:480-7. 
22. Hyman P. Phages for phage therapy: isolation, characterization, and host range breadth. Pharmaceuticals (Basel). 2019;12(1):35.

23. Marek A, Stępień-Pyśniak D, Pyzik E, Adaszek $Ł$, Wilczyński J, Winiarczyk S. Occurrence and characterization of Staphylococcus bacteria isolated from poultry in Western Poland. Berl Münch Tierärztl Wochensch. 2016; 129:147-52.

24. Dec M, Urban-Chmiel R, Gnat S, Puchalski A, Wernicki A. Identification of lactobacillus strains of goose origin using MALDI-TOF mass spectrometry and 16Se23S rDNA intergenic spacer PCR analysis. Res Microbiol. 2014;165:190e201.

25. Clinical and Laboratory Standards Institute. Performance standards for antimicrobial susceptibility testing $27^{\text {th }} \mathrm{M} 100$. Clinical and Laboratory Standards Institute; PA, USA; 2017.

26. Jahan M, Rahman M, Parvej Md. S, Chowdhury Shah Md ZH, Md Haque E, Md. Talukder AK, et al. Isolation and characterization of Staphylococcus aureus from raw cow milk in Bangladesh. J Adv Vet Anim Res. 2015;2:49-55.

27. The European Comitetee on Antimicrobial Susceptibility Testing. 2017 Comité de l'antibiogramme de la Société Française de Microbiologie. Recommandations 2018 V.2.0. 2018. https://www.sfm-microbiologie.org/wpcontent/uploads/2018/12/CASFMV2_SEPTEMBRE2018.pdf.

28. Han JE, Kim JA, Hwang SY, Choresca CH Jr, Shin SP, Jun JW, et al. Isolation and characterisation of a Myoviridae bacteriophage against St. aureus isolated from dairy cows with mastitis. Res Vet Sci. 2013;95:758-63.

29. Marek A, Pyzik E, Stępień-Pyśniak D, Urban-Chmiel R, Nowaczek A. Characterization of bacteriophages and their carriage in Staphylococcus aureus isolated from broilers in Poland. Br Poultry Sci. 2018;60:1-8.

30. Niu YD, Stanford NK, Kropinski AM, Ackermann HW, Johnson R, She YM, et al. Genomic, proteomic and physiological characterization of a T5-like bacteriophage for control of Shiga toxin- producing Escherichia coli O157: H7. PlosOne. 2012;7:1-11.

31. Xie H, Zhuang Z, Kong C, Ma G, Zhang H. Bacteriophage esc-a is an efficient therapy for Escherichia coli 3-1 caused diarrhea in chickens. J Gen Appl Microbiol. 2005;51:159-63.

32. Chibani-Chennoufi S, Sidoti J, Bruttin A, Dillmann ML, Kutter E, Qadri F, et al. Isolation of Escherichia coli bacteriophages from the stool of pediatric diarrhea patients in Bangladesh. J Bacteriol. 2004;186:8287-94.

33. Szermer-Olearnik B, Boratynski J. Removal of endotoxins from bacteriophage preparations by extraction with organic solvents. PLoS One. 2015;10: e122672.

34. Lu's D, Melo R, Sillankorva S, Ackermann HW, Kropinski AM, Azeredo J, et al. Isolation and characterization of a new St. Epidermidis broad-spectrum bacteriophage. J Gen Virol. 2014;95(2):506-15.

35. Wernicki A, Urban-Chmiel R, Balicki I, Świąder K, Dec M, Puchalski A, et al. Sposób otrzymywania kompozycji do leczenia bakteryjnego zapalenia spojówek 1. [a method for preparing compositions for the treatment of bacterial conjunctivitis 1] UPRP P.427798; 2018a.

36. Wernicki A, Urban-Chmiel R, Balicki I, Świąder K, Dec M, Puchalski A, et al. Sposób otrzymywania kompozycji do leczenia bakteryjnego zapalenia spojówek 2. [a method for preparing compositions for the treatment of bacterial conjunctivitis 2] UPRP P.427797. 2018b.

37. Junior AZ, Freitas JC, da Silva Zacarias FG, Salvador R, Garc JL. Investigation of bacterial microbiota and risk factors in dogs with external ocular diseases from Bandeirantes, Paraná state, Brazil. Semina: Ciências Agrárias. 2012;33:3243-50. https://www.redalyc.org/articulo. oa?id=4457/445744118019.

38. Gómez-Sanz E, Sara Ceballos S, Ruiz-Ripa L, Zarazaga M, Carmen TC. Clonally diverse methicillin and multidrug resistant coagulase negative staphylococci are ubiquitous and pose transfer ability between pets and their owners. Front Microbiol. 2019;10:485.

39. Conner JG, Erol E, Locke S, Phillips E, Carter CN, Odoi A. Temporal trends and predictors of antimicrobial resistance among Staphylococcus spp isolated from canine specimens submitted to a diagnostic laboratory. PLoS One. 2018;13:e0200719.

40. Principi N, Silvestri E, Esposito S. Advantages and limitations of bacteriophages for the treatment of bacterial infections. Front Pharmacol. 2019;10:513.

41. Rohde C, Resch G, Pirnay JP, Blasdel BG, Debarbieux L, Gelman D, et al. Expert opinion on three phage therapy related topics: bacterial phage resistance, phage training and Prophages in bacterial production strains. Viruses. 2018;10:178.
42. Pisella PJ, Pouliquen P, Baudouin C. Prevalence of ocular symptoms and signs with preserved and preservative free glaucoma medication. $\mathrm{Br} J$ Ophthalmol. 2002;86:418-23.

43. Coroi MC, Bungau S, Tit M. Preservatives from the eye drops and the ocular surface. Romanian J Ophthalmol. 2015;59:2-5.

\section{Publisher's Note}

Springer Nature remains neutral with regard to jurisdictional claims in published maps and institutional affiliations.

\section{Ready to submit your research? Choose BMC and benefit from:}

- fast, convenient online submission

- thorough peer review by experienced researchers in your field

- rapid publication on acceptance

- support for research data, including large and complex data types

- gold Open Access which fosters wider collaboration and increased citations

- maximum visibility for your research: over $100 \mathrm{M}$ website views per year

At BMC, research is always in progress.

Learn more biomedcentral.com/submissions 